\title{
FIRST RECORD OF Glomerella cingulata CAUSING LEAF BLIGHT ON Talauma ovata (MAGNOLIACEAE) ${ }^{1}$
}

\author{
Bruno Sérgio Vieira ${ }^{2}$, Olinto Liparini Pereira ${ }^{2}$, Márcio Luiz Batista ${ }^{3}$ e Robert Weingart Barreto ${ }^{2}$
}

\begin{abstract}
Glomerella cingulata was found causing severe leaf blight on Talauma ovata, a common tree species in the Atlantic tropical rain forest floodplains of Southern Brazil. The disease and pathogen are described and illustrated and patogenicity is also demonstrated. This is the first report of this disease.
\end{abstract}

Key words: antracnose, ascomycete, forest pathology and ocurrence.

\section{PRIMEIRO RELATO DE Glomerella cingulata CAUSANDO QUEIMA FOLIAR EM Talauma ovata (MAGNOLIACEAE)}

\begin{abstract}
RESUMO - Glomerella cingulata foi encontrado causando severa queima-foliar em Talauma ovata, uma espécie arbórea comum em florestas úmidas tropicais do Sudeste do Brasil. A doença e o patógeno foram descritos e ilustrados, e sua patogenicidade também foi demonstrada. Esse é o primeiro relato dessa doença.
\end{abstract}

Palavras-chave: Antracnose, ascomiceto, patologia florestal e ocorrência.

Talauma ovata A. St.-Hil. (local name magnóliabranca, magnólia-do-brejo, fruta-de-pau) is a forest tree species adapted to alluvial plains along rivers and humid meadows in the neotropics, sometimes forming solid almost homogeneous groups of trees. It belongs to the Magnoliaceae, and although its use is restricted to minor applications for its wood, Lorenzi (1992) recommends its use in programs aimed at regenerating the riverine vegetation as well as in landscaping. In December 2003, during a workshop (Fungi of tropical seasonal semi-deciduous montane forest 2003) aiming at surveying fungi of the Atlantic tropical rainforest, a fungus was found associated to leaf blight symptoms on T. ovata. This work reports this disease and the elucidation of its etiology.

Plants showing disease symptoms were photographed in the field (Fig. 1a). Samples of infected leaves were collected, brought to the laboratory, and dried in a plant press. Isolation were performed by surface sterizing fragments of diseased leaves with necrosis, plating in VBA - vegetable broth-agar medium (PEREIRA et al., 2003), and incubating in the dark at $25^{\circ} \mathrm{C}$ for $48 \mathrm{~h}$. Later the plates were submitted to 12 $\mathrm{h}$ near ultra violet irradiation / $12 \mathrm{~h}$ dark (LEACH, 1962) in plastic Petri dishes at $25^{\circ} \mathrm{C}$. Leaves sections were prepared with a freezing microtome (Leitz Kryomat), adjusted to $30 \mu \mathrm{m}$ thickness and mounted in lactophenol for further microscope observations. Three detached healthy leaves were inoculated throughout the depositing six culture disks taken from 10 days old, VBA medium grown cultures overlaid on wounded and unwounded portions of leaves abaxially and adaxially. Leaves were incubated at $25^{\circ} \mathrm{C}$ for 48 hours in humid chamber after inoculation. Three non-inoculated leaves kept under the same conditions served as control.

\footnotetext{
${ }^{1}$ Recebido em 01.06.2004 e aceito para publicação em 10.08.2005.

${ }^{2}$ Departamento de Fitopatologia da Universidade Federal de Viçosa, Viçosa-MG 36570-000 Brasil.

${ }^{3}$ Departamento de Biologia Vegetal, Universidade Federal de Viçosa.
} 
Lesions on living leaves were circular to irregular, pale brown, taking large portion of the lamina, coalescing and leading to extensive blight, and leaf death (Fig. 1b). The Glomerella cingulata fungus associated to disease is described below:

Internal mycelium inter and intracellular, 2.0 - 4.0 $\mu \mathrm{m}$ diam., branched, septate, hyaline; External mycelium is absent; Ascomata, perithecial, semi-immersed, isolate, globose to obpiriform, dark brown to black, 125 - 175 x $88-130 \mu \mathrm{m}$ (Fig. 1c); Deiscence ostiolar; Intertecial filaments, paraphyses formed in groups at the base of perithecium, septate, unbranched, hyaline; Periphyses on the ostiole canal, septate, unbranched, hyaline; Asci unitunicate, fasciculate, interspersed with the paraphyses at the base of perithecium, clavate to cylindrical, slightly curved, thickened at the apex, 43.0 $-61.0 \times 13.0-15.0 \mu \mathrm{m}$, eight spored (Fig. 1d); Ascospores mostly cylindrical, sometimes oval, $13.0-20.0 \times 3.0$ $-4.0 \mu \mathrm{m}$, aseptate, hyaline, smooth; Anamorph absent; In culture: colony fast-growing $(2.5-3.0 \mathrm{~cm}$ after 3 $\mathrm{d}$ at $25^{\circ} \mathrm{C}$ ), cottony or felty, whitish yellow to brown, dark brown reverse; no sporulation.

The morphology of the specimen is typical of $G$. cingulata as described in Mordue (1971) and Holliday (1980). Material examined: VIC 27790, on Talauma ovata Montane Seasonal Semideciduous Forest, Viçosa, 10/ 12/2003 (Vieira B. S. e Pereira O. L.)

After five days of incubation, typical symptoms were seen on both wounded and unwounded parts of leaves where the inoculum had been deposited. $G$. cingulata was reisolated from the diseased tissues (Fig. 2a), confirming the patogenicity of this fungus. No symptoms were observed on control leaves (Fig. 2b).

No record of this disease was found in the main Brazilian list of fungi on plants (Mendes et al., 1998) or in the world literature consulted. Therefore this represents the first record of this disease. The mycobiota of $T$. ovata in the literature was until now restricted to two species: Berkleasmium talaumae Bat. \& Cavalc., reported on leaves, collected in the Federal District (Brazil) and Xylosphaera cornu-damae (Schein.) Dennis, reported on fruits, collected in the State of Santa Catarina (Brazil) (SILVA e MINTER, 1995). Glomerella cingulata is well known as a cosmopolitan species, specially abundant in the tropics, with a wide host range (HOLLIDAY, 1980), but host specific strains are known to be common at the formae specialis level for this fungus and its anamorphs (WATSON et al., 2000).

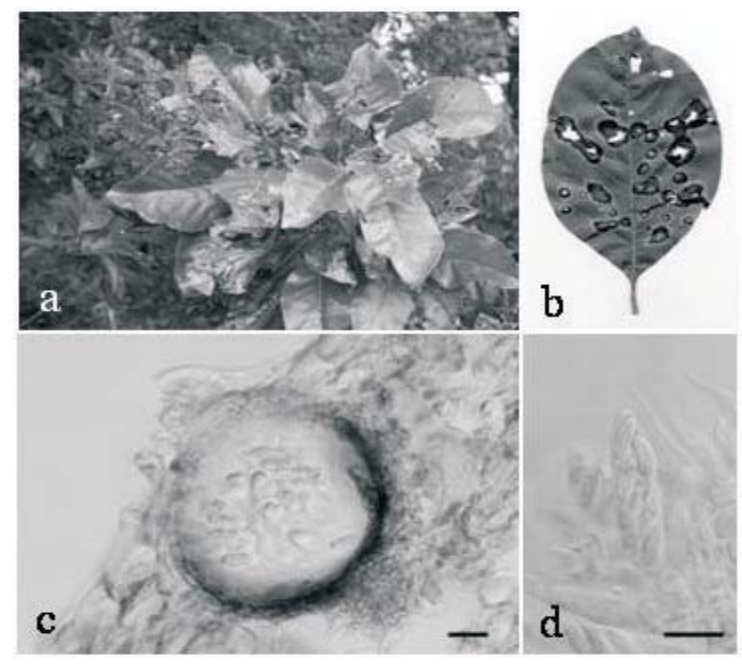

Figure 1 - Glomerella cingulata on Talauma ovata: (a) symptoms on infected plant in the field; (b) detail of symptoms on infected leaves; (c) cross section showing a globose immersed perithecia; (d) asci with ascospores. Bars $=20 \mu \mathrm{m}$.

Figura 1 - Glomerella cingulata em Talauma ovata: (a) sintomas em plantas infectadas no campo; (b) detalhe de sintomas em folhas infectadas; (c) corte mostrando peritécio imerso globoso;e (d) asca com ascósporos. Barras $=20 \mu \mathrm{m}$.

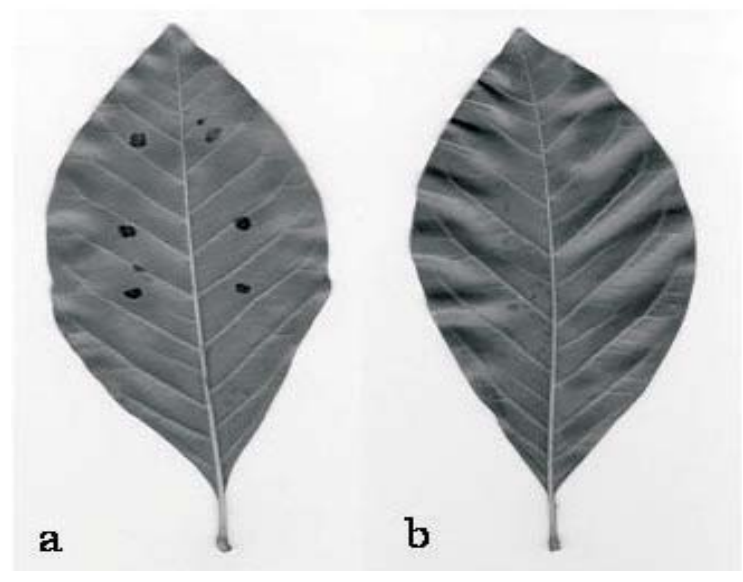

Figure 2 - Inoculation of Glomerella cingulata on Talauma ovata: (a) leaf spot symptoms after inoculation with Glomerella cingulata and (b) non-inoculated leaf.

Figura 2 - Inoculação de Glomerella cingulata em Talauma ovata: (a) sintoma de mancha foliar após inoculação com Glomerella cingulata e (b) folha não inoculada. 


\section{ACKNOWLEDGEMENTS}

The authors wish to thank G. E. Valente for their assistance during field work and the Conselho Nacional de Desenvolvimento Científico e Tecnológico (CNPq) for financial support.

\section{REFERENCES}

HOLLIDAY, P. Fungus disease of tropical crops. Cambridge: Cambridge University Press, 1980. 624 p.

LEACH, C. M. Sporulation of diverse species of fungi under near-ultraviolet radiation.

Canadian Journal of Botany, v. 40, p. 151 $161,1962$.

LORENZI, H. Árvores Brasileiras: manual de identificação e cultivo de plantas arbóreas nativas do Brasil. Nova Odessa: Plantarum, 1992. $384 \mathrm{p}$.
MENDES, M. A. S. et al. Fungos em plantas no Brasil. Brasília: EMBRAPA, 1998. 358 p.

MORDUE, J. E. M. Glomerella cingulata. CMI Descriptions of Pathogenic Fungi and Bacteria. London: The Eastern Press, 1971.

PEREIRA, J. M. et al. Corynespora cassiicola f.sp. lantanae: a potencial biocontrol agent from Brazil for Lantana camara. Biological

Control. v. 26, p. 21-31, 2003.

SILVA, M.; MINTER, D. W. Fungi from Brazil recorded by Batista and co-workers.

Mycological Papers, v.169, p.1-585, 1995.

WATSON, A. K. et al. Colletotrichum Strains for weed control. In: PRUSKY, D.; FREEMAN, S.; DICKMAN, M.B. (Eds.). Colletotrichum-Host specificity, pathology, and host-

pathogen interation. St. Paul: The American Phytopathological Society, 2000. p. 245-265. 